\title{
徵兵検査結果からみたオーストリア・ハンガリー帝国の 地域間格差に関する予察的考察
}

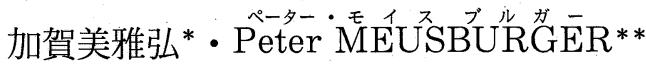 \\ (*東京学芸大学教育学部，**ハイデルベルク大学)
}

\begin{abstract}
本稿は, 19 世紀末のオーストリア・ハンガリ一帝国領内における地域間格差を, 住民の健康状態に着目 して明らかにすることを目的とした，帝国は広大な領域を持ち，国内にある地域間格差がヨーロッパ全域の 地域構造を把握する際にきわめて有意義であることが指摘されていながら, 地理学においてはこれまでまっ たく議論されてこなかった，本稿では，『軍統計年鑑』に掲載されている徴兵検査結果に注目し，地域差を 呈する住民の健康状態から地域間格差を論じた，具体的には，健康状態を全般的に示すと考えられる身体の 衰弱と低身長，さらに異なる地域的要因を持つ疾病として甲状腺腫，クレチン病，歯の疾患を取り上げ，そ の地域差を検討した.

これらの地域差を描写した結果, 徵兵検査に代表される住民の健康状態の地域差が, 地域の経済水準や医 療・衛生施設の整備, 生活水準の地域差と関わること, この地域差が地域外から流入するイノベーションや 地域住民のイノベーション受容によって規定されるとの解釈を提示した，19 世紀後半は，帝国において鉄 道建設をはじめとする近代化が進行した時期にあたり，健康状態の地域差はかかる近代化のプロセスの地域 差を反映するものであるといえる.
\end{abstract}

キーワード : 地域間格差, 社会指標, 健康状態, 徵兵検査, オーストリア・ハンガリー帝国

\section{I はじめに}

本稿は, 19 世紀末におけるオーストリア・ハン ガリ一帝国1) (以下，帝国と略する）領内における 住民の健康状態の地域差に着目し，帝国内の地域間 格差についての考察を試みるものである.

地域住民の健康状態が地域間で異なることは，古 くヒポクラテス以来，指摘されてきた事実である. 住民の健康状態は地域間で異なる自然的・社会経済 的諸条件によって規定されるものと考えられ，ゆえ に地域住民の健康状態一般の地域差は，さまざまな 要素からなる複合体としての地域の特性を反映した ものとみなされてきた (Learmonth 1988: 5-8). 地理学では, とくに疾病の空間的パターンを把握し, その規定要因を明らかにすることに主な関心が払わ れてきた。 それは, 特定の疾病の地域的多様性を地 図に表現し, 疾病と地域を構成する諸要素との関係 を追究するという手順を踏みながら, 疾病を地理学 的事象として位置づけようとする医学地理学のフレ
ームワークの中で試みられてきたものであった（加 賀美・粐山 1982)2).

興味深いのは, 健康状態の地域差が，社会の空間 的不平等に関心を置く社会地理学においても議論さ れてきたことである. たとえばドイツ語圈では，と くに 1970 年代以降, 生活水準の地域差を測る指標 として地域住民の健康状態が注目されてきた3)。死 因別死亡率や乳児死亡率の地域差が，自然条件はも とより所得，教育や医療など諸サービスの空間的不 平等を反映したものであるという前提から，地域住 民の健康状態や受療行動の社会指標としての位置づ けが模索されている (Maier and Troeger-Weiß 1987).

ところで, 健康状態の地域差を把握する際には適 切な空間的スケールを設定する必要がある．分析の スケールによって求められる結論は異なるであろう し，適切なスケールを選択することによってより深 い考察が可能になるからである.つまり空間分析に 際しては，現象の空間的差異がより明瞭に現れる空 


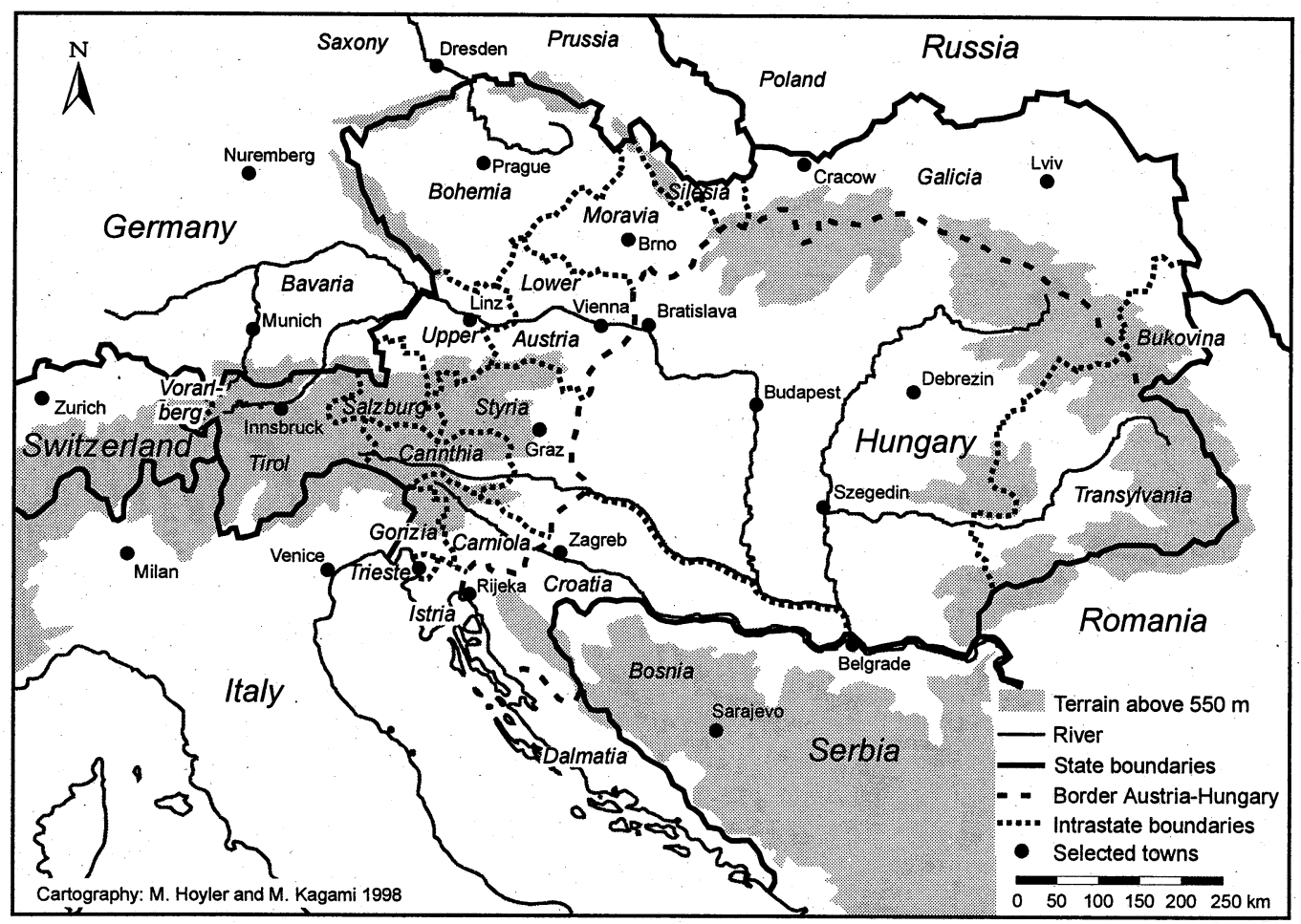

図 1 オーストリア・ハンガリー帝国 (1875 年)

Fig. 1 The Austro-Hungarian Empire, 1875

After Gross (1985: 204)

間的スケールが前提になる. しかし, 健康状態に関 する入手可能なデータが著しく限定されていること から，この点を考慮して研究対象を選択することは 容易ではなく, 社会指標としての健康状態の有用性 を示すためにはより多くの事例分析が必要である.

本稿が対象とするオーストリア・ハンガリー帝国 は, ヨーロッパの中央部において，自然環境はもと より歴史的背景の異なるきわめて多彩な特性を持つ 地域を抱え込んでいた（図 1 )。一方，19 世紀後半 のヨーロッパは, 産業革命の波が北西ヨーロッパか ら次第に広い範囲に拡散し, 都市化, 近代化がヨー ロッパ各地で進展した時期に該当する。帝国内にお いても人口や物資の移動が急増し, 生活水準は全体 的に向上し，労働はじめ教育や諸サービスの機会は 増加した. 反面, それは地域間の格差が顕在化した
時期でもあった（Gross 1985).

この時期のヨーロッパでは, 住民の健康状態もき わめて明瞭な過渡的傾向を示した (Spree 1981: 42-49). つまり, 伝染病の一時的な流行を除けば, 伝染病から慢性病, 局地発生型（風土病）から広域 発生型への疾病の種類の变化が, 社会経済的条件の 変化に伴って急激に進展した4). 帝国においても同 様の変化が見られ (Prinzing 1906: 86-89), しか も多様な地域からなるために社会経済的条件の変化 の度合いは地域的に異なっていた。 ゆえにこれに 応じて疾病の種類や住民の健康状態も空間的に異な っていたと考えられる.この点で, 帝国は, 健康状 態の地域差に基づいて地域の社会的側面を論じるた めの格好の対象地域であると考える.

本研究の今日的な意義も付言しておきたい，昨今 
の中央・東ヨーロッパの情勢において，そこに位置 する国家それぞれの現状と今後の動向が積極的に検 討されている5). 一方, この地域が歴史的, 文化的, 社会的にきわめて多様な特性を有するゆえに, 個々 の国家ごとではとらえ切れない地域間格差を拾い上 げることも必要であろう. 実際, 地域間格差の存在 を否定してきた社会主義体制が崩壊した今, 社会福 利に代表されるような空間的不平等がことさらに露 呈し，その是正が重要な課題になっている(Zaniewski 1992; Meusburger and Klinger 1995: V-XII). これに対して，帝国時代に編集された精緻な統計は, 帝国領であった中央・東ヨーロッパの広い範囲での 格差を一括して把握できる貴重なデータであると評 価できる. ヨーロッパにおける地域間格差が持続性 を持つ（Ehlers 1997）という前提に立てば, 本研 究は現在の中央・東ヨーロッパの特性を理解する一 助となるはずである.

\section{II 健康データとしての帝国の徵兵検査結果}

地域住民の健康状態に関する資料は，プライバシ 一保護の理由から著しく限定されている.たとえば 従来の医学地理学研究では, 主に死因別死亡統計が 住民の健康状態を把握する際に用いられてきた. 死 亡統計は各国において整備され, 疾病分類に基づい て集計されており, 疾病別の検討が可能であること, それらの入手が比較的容易であるなどの理由から重 要な研究対象とされてきた. しかし, 死因とは死亡 の直接の原因となった疾患であること，すなわち死 因はそれまで罹っていた疾患とは必ずしも一致せず, 日常の健康状態を十分に反映したものとは言い難い (Jones and Moon 1987). そこで, 死亡統計とは 別に, 地域に生活する住民の健康状態をより直接的 に反映するような資料（以下，健康データと略す

る) が模索されている6).

徵兵検查結果に関するデー夕は, 比較的早い時期 に統計として整備され, ゆえに地域住民の健康状態
を示すものとして注目されてきた資料である. 今世 紀初めにはすでに, ヨーロッパ各国の国民の健康水 準を比較するために, 徽兵検査および健康診断に関 する軍の統計が頻繁に用いられている7). 近年では, 受検者の健康状態と地域の社会経済レベルとの対応 関係が, 主に歴史学や社会学において繰り返し論じ られている (Tilly 1992). 日本でも北原 (1977) が, 社会学の立場から, 軍隊が質のよい兵士を確保する ために保健衛生問題を重視し, 徵兵検査を通じて国 民の保健衛生状態を探知していた点を取り上げ, 当 時の社会を把握する際の徽兵データの有用性を指摘 している8). また，とくに検査項目の一つである身 長は，受検者の栄養摂取状況と対応する点で地域社 会の変化をとらえる有効な指標として注目されてき た (Komlos 1989: 3-20; Floud et al. 1990: 1620).これは, 地域住民の栄養状態が彼らの所得や 職業など経済活動を反映し, また間接的であれ, 衛 生や交通など地域のインフラストラクチャーの水準 を反映することを前提にしたものである. とくに Komlos (1989: 160-165) は, 受検者の身長を, 産業革命に伴う地域変化のメカニズムを解明するた めの指標としての意義を確認している.

オーストリア・ハンガリー帝国では, 1870 年か ら 1914 年まで毎年 20 歳の男子全員を対象にした 徵兵検查が実施され9), その結果が『軍.統計年鑑 Militärstatistische Jahrbuch $\rrbracket^{10)}$ の「医師による 徵兵検査結果」の項に掲載されている11). 注目すべ きは, 不適格の理由として疾病や障害名が記録され たことである，検査は軍医と民間医を含む委員会に よって実施された信頼度の高いものであり ${ }^{12)}$ ，これ によって当時の住民の健康状態が帝国全域にわたっ て把握されていた (Friedl 1979).

『軍統計年鑑』には, 1870 年から 1911 年にわた って軍管区 Militärbezirk およびその下部組織で ある補管区 Ergänzungsbezirk ごとに，不適格理 由が千人あたりの比率で，また低身長ゆえに不適格 
になった者の数が実数で掲載されている ${ }^{13)}$.

帝国における徵兵検查結果を一瞥しょう。徵兵検 查結果をヨーロッパ諸国間で比較した Prinzing (1906: 233-237) によれば，帝国の状況は明らかに 他の国々とは異なっていた。 つまり，1870 年の徵 兵検査開始以来，帝国における適格者の検査該当者 に占める割合は一貫して約 $20 \%$ 前後と低く，低身 長や身体上の障害による不適格者の割合が 50〜60 \%という值を維持していた. 兵力増大のために徴 兵検査基準が緩和される傾向にあった当時, 帝国に おける不適格者の割合はフランスやドイツなどヨー ロッパの隣接諸国に比べてきわめて高い水準であっ た ${ }^{14)}$ 。これは，帝国内に不適格者の割合が極端に高 い地域が存在することを示唆する一方で，ヨーロッ パ全域における健康状態の地域差を提示するもの之 しても興味深い. いずれにせよ，いくつかの疾病・ 障害の地域差をとらえることによって，帝国内にお ける地域間格差を考察することが可能と考える ${ }^{15)}$.

帝国内の地域間格差は, これまで地理学において はほとんど議論されてこなかった ${ }^{16)}$. 歴史学の立場 から Good（1986）が州別に地域間格差を論じたこ とを除けば，小単位地域をべースにした詳細な地域 間格差は, Meusburger (1991, 1995), Hoyler and Meusburger (1997) によって, ようやく分析の対 象になったといってよい.

Meusburger (1991) と Hoyler and Meusburger （1997）は，住民の識字率に着目し, 帝国内の地域 間格差が住民の識字能力によって生み出される点を 示唆している.これは, 識字能力がとくに 19 世紀 後半のヨーロッパにおいて, 工業化や近代化の進度 の地域差をもたらした重要な要因であると結論づけ ている. 識字率の高い地域では, 地域外からの新し い情報や技術が比較的容易に受容され，工場など新 しい産業資本の流入を促した. その結果, 所得水準 など住民の生活水準は識字率の地域差と対応するよ うになった (Meusburger 1998: 254-256)。いうま
でもなく，住民の生活水準は彼らの健康状態之密接 に関係する.この点については, Meusburger (1995) が徴兵検查結果に着目し, データの信憑性 とその整理方法を提示している. しかし, 帝国内部 の地域間格差にはほとんど言及していない，そこで 本研究は, 社会指標の一つである住民の健康状態に 着目し, 住民の識字能力がこれに密接と関わる点を 考慮しながら，地域間格差を論じる．これによって， きわめて複雑な構造をなしているであろう近代化と いう地域変化のプロセスを, より具体的に把握する ことが可能であると考えるからである.

以下では，オーストリア・ハンガリー帝国におけ る徵兵検査結果を用いて地域住民の健康状態の地域 差を明らかにし, 帝国内の地域間格差に関する考察 を進める.ただし，疾病の分類方法が調查年によっ て異なるために経年的な比較が困難なので, 本稿で は, 分類に変化がなく比較的資料が整っている 1873 年と 1885 年における健康状態の地域差を検討 する. 具体的には, 住民の健康状態をより一般的に 示すものとして, 身体の衰弱と低身長, 特定の疾 病・障害として, 異なる地域的要因によって生じる とみられる甲状腺腫, クレチン病, 歯の疾患を取り 上げ, 地域的諸要因との関わりを考察するという手 順を踏む. なお, その際, 軍管区や補管区の区域が 調查年によって異なり，しかもこの区域が国勢調査 など他の統計の調査区域之一致しないなどの問題が あるため,ここでは統計的な手法を用いることがで きず，したがって可能な限りの解釈を施すことに主 眼を置く。

なお，地名は日本語の慣用名があるものを除いて， 当時の統計にある表記に従い, 必要に応じて適宜現 在名を併記する.

\section{III＼cjkstart帝国における健康状態の地域差}

1. 身体の衰弱および低身長の地域差

身体の衰弱は，医学的に定義された概念ではない。 

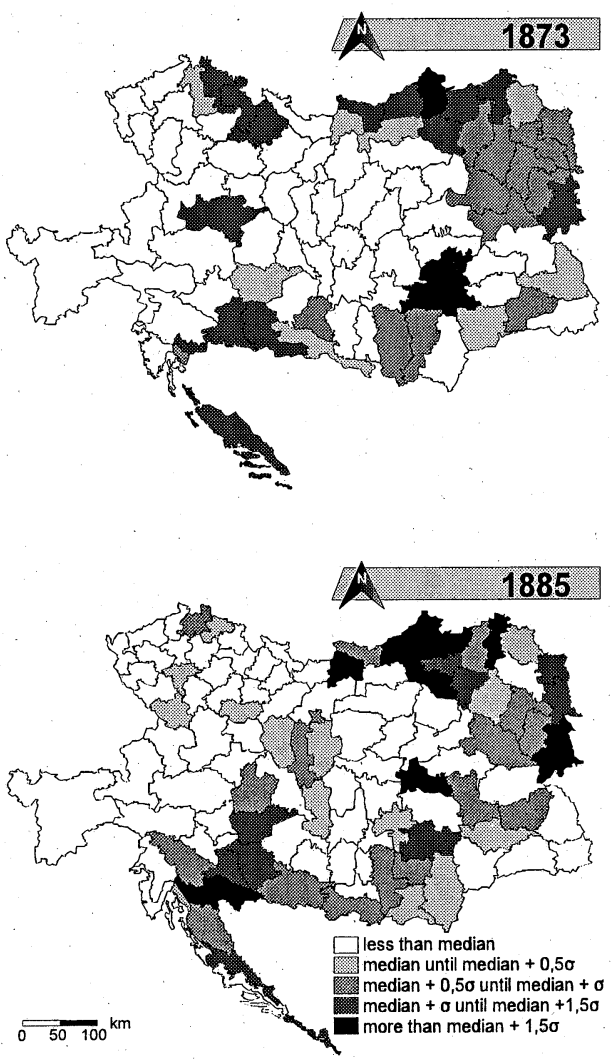

図 2 身体の衰弱の地域差 南部の沿岸地方の軍管区の再編により両図は異なる. 以下, 図 $3 \sim 6$ も同様.

Fig. 2 Regional disparities in generalized weakness of the body

Source: Militärstatistisches Jahrbücher

しかし，一般的には栄養不良や発育不全などが想定 される (Meusburger 1995: 216，219)。 むしろ, これは疾病や障害が特定できない受検者に対する最 も簡便な診断結果として用いられた. この点で, 身 体の衰弱は不適格者の全般的な健康状態を代表して いる.

徵兵検査の結果, 身体が衰弱していると診断され て不適格となった者の割合は, 1873 年と 1885 年の いずれにおいても地域的に著しく異なっている（図 2). とくに割合の高い地域には, 帝国東部のカル パチア山脈, ガリツィア地方（現ウクライナ西部）, 南部のバナート地方（現セルビア北部）やスラヴォ
ニア地方 (現クロアチア東部), ダルマチア地方 (現クロアチア南部), さらにボヘミア地方 (現チェ コ西部）北縁を走るエルツ山地などがあげられる.

いずれも首都ウィーンから辟遠の地にあり, 農業が 主体の地域である．他の地域を結ぶ交通が十分に整 備されておらず，とくに東部地方は農奴制など古い 社会体制が長く存在した地域として特徵づけられる (Good 1986: 113-143).

一方，身体の衰弱を理由とする不適格者の割合が 低い地域として, 帝国西部のオーバーエスターライ ヒ, ザルツブルク, ケルンテン, シュタ.イヤーマル ク, チロルなど現在のオーストリアの諸地方を構成 する補管区, ボヘミ゙ア地方南部, モラヴィア地方 (現チェコ東部), ハンガリー中西部の諸地域があげ られる. これらの地域では, ウィーンをはじめ, 隣 接するドイツや北イタリアと連絡する交通網が比較 的早い時期に整備され, 新しい物資や技術, 情報が 浸透した. いずれも 19 世紀後半の帝国において, 工業化を軸に地域経済がより発展した地域として位 置づけられる (Good 1986: 116-130).

このような地域差が地域の社会経済的特性と密接 に関係していることは，このパターンが受検者の身 長と対応していることからもうかがえる ${ }^{17)} .1873$ 年において，低身長 $(155 \mathrm{~cm}$ 未満) ゆえに不適格 になった者の割合を集計すると，帝国北部や東北部 (ズデート山脈, ガリッィア地方, カルパチア山脈 北半部の諸地方）から南方に向けて帯状に広がる地 域に高い值が見られる(図 3 ). また, 帝国東端の卜 ランシルヴァニア地方 (現ルーマニア西部)の南部に も，身長が低い受検者の割合が帝国平均の $50 \%$ ，以 上も高い値を示す補管区が見られる. 1885 年にも ほぼ同様の地域差が認められる，とくに帝国北東部 のガリツィア地方を中心とする地域において，低身 長による不適格者の割合が目立って高くなっている.

身体の衰弱および低い身長を理由とする不適格者 の割合の地域差をそれぞれ対照すると, 南部のクロ 

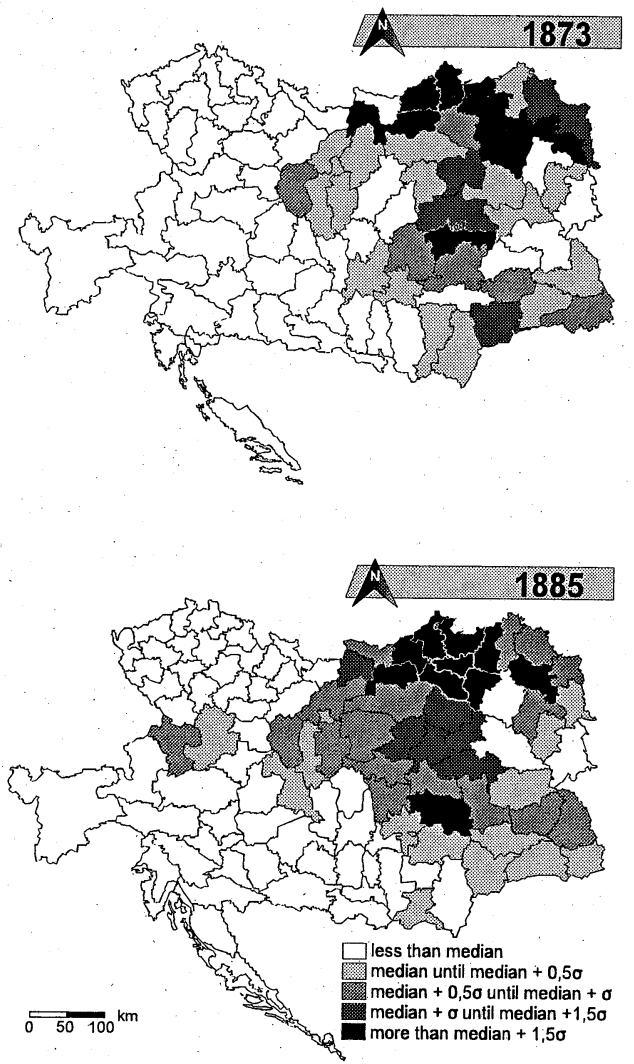

図 3 低身長の地域差

Fig. 3. Regional disparities in short physical stature

Source: Militärstatistisches Jahrbücher

アチア地方において身体の衰弱の割合が高くなって いる点を除けば，きわめて類似のパターンが認めら れる.つまり，いずれの比率も高い帝国東部や東北 部の諸地域には, 西部の地域に比べて明らかに住民 の健康状態一般にとって不利な特性が存在すると考 えられる，言い換えれば，この地域差は，健康状態 一般に関与する住民の生活水準が帝国内において東 西間で明瞭に異なることを示している.

\section{2. 特定の疾病の地域差}

1 ）甲状腺腫

甲状腺腫は山岳地域に多発する傾向がある．とく に, かつて氷河に覆われた地域では, 土壤中のヨー
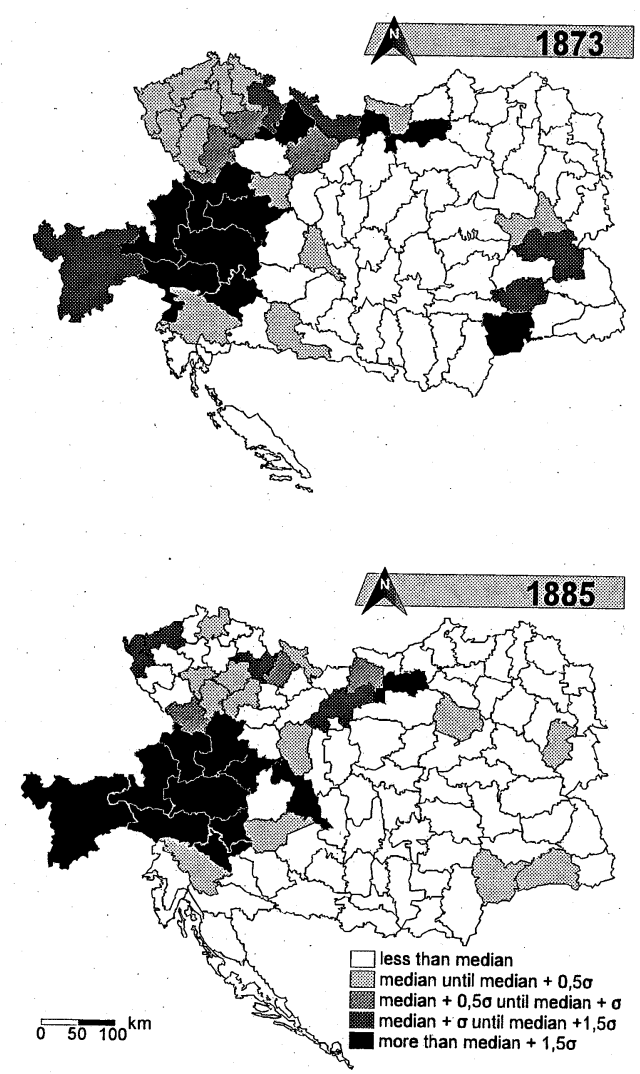

図 4 甲状腺腫の地域差

Fig. 4 Regional disparities in the incidence of goiter

Source: Militärstatistisches Jahrbücher

ド含有量がきわめて少ない傾向があり，それゆえに そこに栽培された農作物を摂取する人々が発病しや すいことが確認されている．これは，甲状腺腫が体 内でのヨード欠乏によって起こる甲状腺異常を原因 とするからである (Wörterbuch-Redaktion des Verlages 1998: 1520-1521)。このような発病プロ セスは，その土地で栽培された畑作物のみに依存す るような伝統的な食習慣によって促される傾向があ る. ゆえに甲状腺腫は, 地域の環境亡密接に関係し た, 局地的に発生する風土病としてしばしば位置づ けられている (Learmonth 1988: 303-308).

帝国においては, 甲状腺腫を理由とする不適格者 の割合は, 1873 年および 1885 年のいずれも帝国西 
部のアルプス山岳地に集中しており, グラーツやク ラーゲンフルト, インスブルック, ザルッブルク, リンツ, マールブルク（現スロヴェニアのマリボ ル）などの補管区で最も高くなっている。 また，帝 国北部のボへミア地方からモラヴィア地方やガリツ イア地方にかけての地域, 東端部のトランシルヴァ 二ア地方にも高い値の補管区が分布する（図 4).

これらはそれぞれ，ボへミア北部のエルツ山地から ズデート山脈, タトラ山地に続く山岳地, トランシ ルヴァニア地方を走るカルパチア山脈に対応してい る. とくに帝国西部の補管区では, いずれの時期に おいても甲状腺腫を理由にした不適格者の割合がき わめて高くなっている.

これに対して, 甲状腺種による不適格者の割合が 低いのは, ハンガリー平原の広い地域, ガリツィア 地方東部の首邑レンベルク（現ウクライナのリヴォ フ）からブコヴィナ地方（現ウクライナ西部）に至 る地域, カルパチア山脈の東部, ダルマチア地方な どの地域である. いくつかの例外はあるものの, こ れらは総じて平野部を占めている.

甲状腺腫による不適格者の割合の地域差が，この 二つの時期において類似の地域的パターンを示して いるのは, 甲状腺種の発生に関わる土㙵条件が克服 されず, しかも山岳地における雑穀食に代表される 旧態依然の生活様式の存在を示唆していると考えら れる. しかし，このことが必ずしもこれらの地域経 済・社会の停滞性を示すことにはならない，地域に おける食習慣の变化は, 生業・技術・情報などの变 化とは別に，比較的ゆっくり進行するからである ${ }^{18)}$.

では, 甲状腺腫が比較的生活水準が高いとされる 帝国西部に集中していることを，どのように説明で きるであろうか. 帝国全域において西部地域の経済 水準が高いのは, この時期に急成長を遂げた都市が 同地域に集中するからであり, 実際, ウィーンをは じめとする都市には, 高所得ゆえに栄養・衛生水準 の高い人々が増加しつつあった（Spree 1981: 128-
133)、にもかかわらずこの疾患の割合が帝国西部で 高いのは，都市とは対照的に農山村では依然として 旧態の生活様式が維持され, 甲状腺腫発生の温床に なっていたからであろう. 19 世紀後半の帝国西部 では, 都市の発達に伴って都市・農村間の経済格差 が拡大しつつあり (Hoyler and Meusburger 1997: 3-5), そのことをこの疾患の地域差からも指摘する ことができる.

\section{2) クレチン病}

クレチン病は, 胎児期における甲状腺機能障害, 不十分なホルモン代謝などを原因とし, 甲状腺の障 害や骨格, 神経・聴覚器官などの発達不全を伴う疾 患の総称である (Wörterbuch-Redaktion des Verlages 1998: 871). しかし, 19 世紀にはこの病 気は, 知能障害や無気力などの典型的な症状に基づ いて，山岳地域に局地的に見られる精神薄弱などの 精神障害を伴う身体不全全般を包括するものとされ た (Höfler 1899: 329-330). 帝国の徵兵検査では, クレチン病はてんかん, 聴覚・言語障害とともに神 経の疾患として分類されている．この分類は現代の 疾病分類とはかけ離れているが, 本稿ではクレチン 病を精神障害の一つとしてとらえることにする.

帝国内におけるクレチン病による不適格者の地域 差を見ると, 1873 年と 1885 年のいずれにおいても 帝国西部のザルツブルクやチロル補管区およびその 周辺に，高率の地域が集中している. さらに 1873 年には, 帝国東端部のトランシルヴァニア地方南部, 1885 年には帝国北部のボヘミア地方からガリツィ ア地方にかけてのいくつかの補管区が高率地域とし て指摘できる (図 5 ). いずれもアルプス, ズデー ト山脈からタトラ山地に至る地域, カルパチア山脈 南部など山岳地域に集中する傾向を示している.

山岳地に多発する精神障害については, 従来から 隔絶山村に多く見られた近親婚との関連性が指摘さ れている (Kagami 1992: 9). 地形的条件ゆえに 孤立した山地集落では, 住民の空間的移動は極度に 

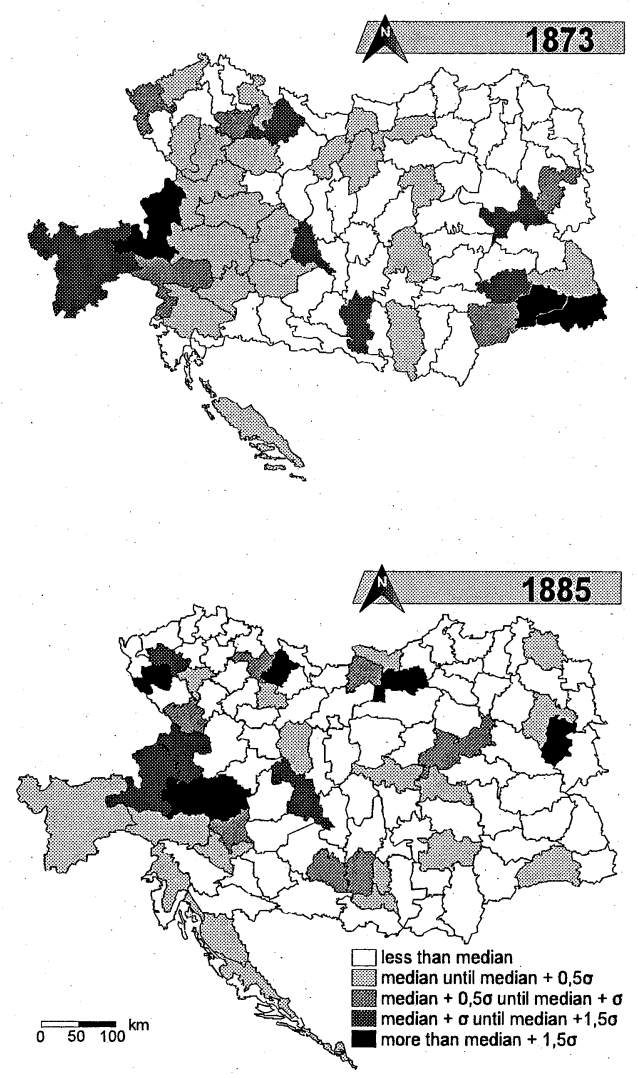

図 5 クレチン病の地域差

Fig. 5 Regional disparities in the incidence of cretinism

Source: Militärstatistisches Jahrbücher

制限され，通婚圈は著しく限られていた ${ }^{19)}$. その結 果, 先天性の精神障害は, 死産や乳児死亡の頻度を 高めるとともに，このような極端な縁辺地域で多発 する傾向を示した (Höfler 1899: 329-330).なお, クレチン病の発症に性差がほとんどないこと, また 高齢のクレチン病患者も少なくないこと（Wörterbuch-Redaktion des Verlages 1998: 871) から, 徵兵検查の対象である青年男子に認められる本病の 発症頻度の地域差は, 住民のクレチン病の発症を反 映しているといえる. したがって，ここに示される クレチン病の地域差は, とくに帝国西部の山間地に おける人口流動量の乏しい地域の性格を示唆してお り, この点で甲状腺種と同様に，帝国西部における
都市・農村間の経済格差を測る指標として興味深い.

3 ) 歯の疾患

ここでいう歯の疾患とは, 融歯を含む歯の欠損全 般を指す. 19 世紀後半には, それまで多発してい た伝染病のような地域の自然条件や住民の伝統的生 活様式之関連する疾病が減少する一方で, 生活様式 の変化に伴って従来少なかった疾患が多発するよう になった (Seidler 1993)。歯の疾患は, 都市的生 活様式の普及, 所得水準の向上など工業化や都市化 の進行に伴う食事内容の変化と対応していたと考え られる. 19 世紀後半には, ヨーロッパの都市部で は従来の穀物など植物性食品主体の食事内容から, 肉や乳製品など動物性食品の比重が高い食事内容へ と変化した. また, 砂糖のような嗜好品も庶民の手 に入るようになるなど，いわゆる食生活革命が起こ った（南 1998: 43-51，79-80，143-146).一方，こ の時期における生活様式の变化を見ると, 社会階層 間での格差は拡大した. 工業化や近代化に伴って生 活様式が変化する一方で, 健康や保健に関する意識 には著しい格差があった (Spree 1981: 128-133). その結果, こうした両者の涐離によって伝染病をは じめとする疾病の発生が多数確認された。 このこと を具体的に歯の疾患に当てはめると，おおかたの市 民には歯磨きの習慣がまだ普及しておらず, 受療の 機会も著しく少なかったことがこの疾患の発生を促 したのではなかろうか. 実際, ここでいう歯の疾患 が, 兵役に不適格と判断されるほどの重度の障害で あって，それが地域的に偏って見られるとすれば, そこには地域の生活水準や社会的・衛生的条件が何 らかの形で反映されることが予想できる.

歯の疾患による不適格者の割合は, 1873 年と 1885 年のいずれにおいても，とくに帝国の北西部 つまりボヘミア北部，オーストリア東部からウィー ンにかけての地域, そして南部のイストリア半島周 辺部で高くなっている(図6).19 世紀後半のボへ ミア地方北部には，ガラス工業や製糖業を中心とす 

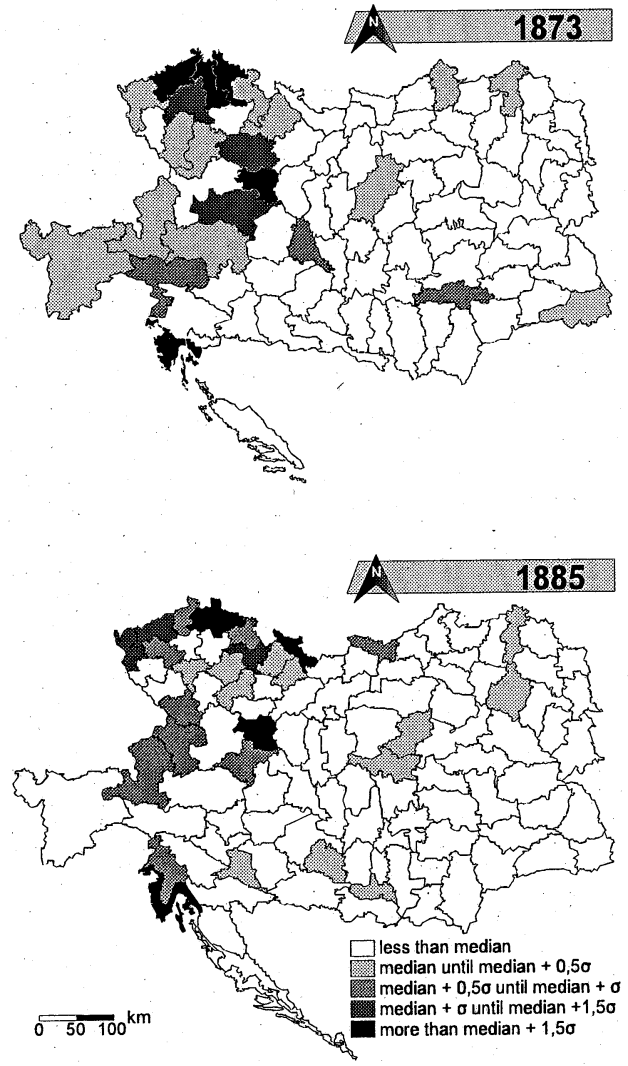

図 6 歯の疾患の地域差

Fig. 6 Regional disparities in the incidence of dental disease

Source: Militärstatistisches Jahrbücher

る加工業が発達し中小の工業都市が立地する, 帝国 でも最も工業化が進んだ地域の一つであった (Gross 1985: 225)。また，オーストリア北部には 工業都市リンツと首都ウィーン, アドリア海に面す るイストリア半島周辺には, 帝国の二大港湾都市卜 リエスト（現イタリアのトリエステ）とフィウメ (現クロアチアのリエカ) がそれぞれ立地する．ウ ィーンの外港として早くから整備されたトリエスト と並んで, フィウメはとくに 1878 年以降のハンガ リーの好景気によってブダペストの外港としてにわ かに活況を呈することになった. 帝国内においても， とりわけ人口流入と都市施設の整備など急速に都市 化が進んだ地域として位置づけられる (Good 1986:
121).

歯の疾患による不適格者の割合は, 明らかに帝国 の西部の工業化や都市化が進展した地域において高 くなる傾向が認められる. それは，とくに都市部に おいて動物性食品の割合が高い新しい食事内容が受 容され, 食品の増加による栄養水準の向上が進行し たことと関係している(Höfler 1899). その結果, これらの地域では, 伝染病や遺伝病などの疾患が減 少し, 代わって歯の疾患が増加するという変化が生 じた．実際，歯の疾患が甲状腺腫やクレチン病とは 対照的な地域差を示しており，これらの疾病ごとの 地域差が, 帝国内の近代化の空間的差異と対応して いると考えられる.

\section{IV 住民の健康状態と地域的諸要因}

地域住民の健康状態が彼らの生活水準と対応して いることは，疾病の種類や死因の動向に関する分析 によって，すでに指摘されている20)。ここでは，健 康状態と生活水準の関係を前提にして, 帝国内にお ける住民の健康状態の地域差と地域的諸要因との関 わりを考察しょう.

一般に生活水準の向上は，とくに食事内容や居住 環境の改善を基軸にしながら進行する，具体的には， 動物性食品摂取量の増加とそれに伴うエネルギー摂 取量の増加, 食事内容の多様化が進行し，それによ って住民の体力は高められる (Murken 1992: 153158)，また住環境，とくに上下水道の整備が伝染病 の流行を抑えるので, 結果として乳児死亡率は低下 し，住民が罹患する疾病・障害も変化する (Seidler 1993: 247). その結果, 工業化や都市化の進行とと もに，生活水準が向上し，風土病のような伝統的生 活様式と密接に関連する疾病が次第に克服される反 面, 新たな疾患が多発することになる (Learmonth 1988: 24-27). この点で, 本稿で提示した健康状態 全般を示す身体の衰弱や低い身長，風土病的性格を 持つ甲状腺腫とクレチン病, より新しい生活様式と 
の関連が考えられる歯の疾患の地域差は, それぞれ きわめて示唆に富んでいる.

生活水準の向上は, 地域のさまざまな変化と連動 している. とりわけ地域経済の発展は, 失業率の低 下, 所得の増大, 高学歴者向けの雇用機会の増加な どをもたらす上に，医療・衛生施設の拡充・整備を も促す (Schaffer 1997)。 また, 病院の設置, 医 療担当者の配置によって, 地域住民の健康状態は直 接的に変化することにもなる.

ところで，このような地域レベルでの生活水準や 地域経済の変化は, 地域住民によるイノベーション の受容の程度いかんで大きく異なる．より多くのイ ノベーションを受容することによって, 新しい生活 様式や新しい生産形態, 投資, 高学歴者向けの雇用 機会の増加などがもたらされるからである (Meusburger 1998: 30-33)。ここでいうイノベーション とは，たとえば鉄道の開通，工場の進出，住宅や商 店の建設, 新しい生活物資の流通などであり, これ らと連動する賃金水準の向上が生活水準を変化させ ることになる，その際，イノベーション受容の程度 は, いくつかの地域固有の要素によって規定される が, ここでは意思決定者としての地域住民の資質, とくに彼らが持つ知識の量の多寡を, イノベーショ ン受容を左右する要素として指摘しよう.

住民が持つ知識の量は，いうまでもなく就学率や 就学期間など住民の教育水準と密接に関係する. ま た季節労働や通婚, 通商など住民の空間的移動の機 会の増大などによっても規定される. より広い地域 に関する知識, 個人主義などの新しい生活規範や価 值観に関する知識, 新しい技術や生活様式に関する 知識が, イノベーションの受容を促す結果になる. 初等学校への就学率の上昇や食事内容の改善は, 19 世紀後半のヨーロッパが近代化とともに経験したも のであるが，この近代化のプロセスは，住民が持つ 知識の量の増加と, イノベーション受容の進行を意 味すると考えられる.
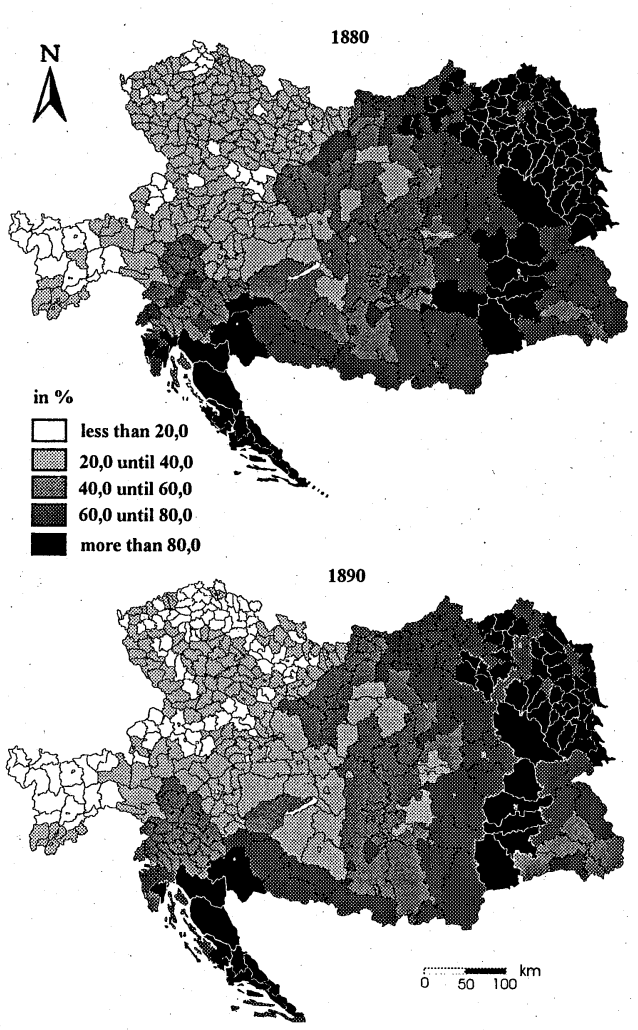

図 7 非識字率の地域差

Fig. 7 Regional disparities in illiteracy rates After: Meusburger (1998: 270)

では，これらの変化が地域住民の健康状態とどの ように連動するのであろうか. たとえば Meusburger (1998: 244-245) は,' 子供の識字能力・知識の 量と母親の識字能力・学歴との関係を分析し, 地域 住民の識字能力が女性の教育水準によって強く規定 される点を指摘している. 一方, Komlos (1989: 42）によれば，母親の教育水準が低い場合には，子 供の栄養レベルは低下し，乳児死亡率を高め，身長 は伸びない傾向にあるという。.ある地域における住 民が持つ知識の量と健康状態の関係が, 女性の教育 水準によって結びっくという指摘は重要である.

教育水準と健康状態，および地域の経済水準との 関係は，帝国においても指摘できる．帝国内での住 民の非識字率の地域差を見ると (図 7 ), 非識字率 が低い帝国西部のチロルやボヘミアの諸地域と, 非 
表 1 受検者に占める身体衰弱による不適格者の割合（民族集団別）

Table 1 Generalized weakness of the body as a reason for excluding recruits from military service by ethnic group

\begin{tabular}{cccccccc}
\hline Year & German & Czech & Pole & Ukranian & Hungarian & Romanian & Croatian \\
\hline 1872 & 23.5 & 25.4 & 43.2 & 29.5 & 24.7 & 34.8 & 42.9 \\
1879 & 34.1 & 49.7 & 54.2 & 55.3 & 36.7 & 48.7 & 49.1 \\
1885 & 50.9 & 51.7 & 74.9 & 63.9 & 53.7 & 56.6 & 71.1 \\
1890 & 39.9 & 39.8 & 51.9 & 57.5 & 58.8 & 69.5 & 66.9 \\
1895 & 42.3 & 46.5 & 56.5 & 59.1 & 45.9 & 44.5 & 55.6 \\
1900 & 31.1 & 33.5 & 45.8 & 46.8 & 37.5 & 46.4 & 56.8 \\
1905 & 41.8 & 38.7 & 44.1 & 53.4 & 42.6 & 54.1 & 42.9 \\
1911 & 46.4 & 49.3 & 49.7 & 51.1 & 50.1 & 52.8 & 45.9 \\
\hline Average & 38.8 & 41.8 & 52.5 & 52.1 & 43.8 & 50.9 & 53.9 \\
Minimum & 23.5 & 25.4 & 43.2 & 29.5 & 24.7 & 34.8 & 42.9 \\
Maximum & 50.9 & 51.7 & 74.9 & 63.9 & 58.8 & 69.5 & 71.1 \\
\hline
\end{tabular}

識字率が高い帝国東部のガリッィア，トランシルヴ アニアの諸地域，南部のクロアチア，ダルマチアの 諸地域との対照を確認することができる.これは, 徵兵検查結果における身体の衰弱や低い身長を理由 とする不適格者の割合の地域差と類似している．す でに述べたように，帝国内にはかなり明瞭な西高東 低の経済格差があるが，住民の識字能力も健康状態 もこれとよく一致している．つまり，識字能力と経 済水準が密接に関係することが，ここに読み取れる. 実際，識字能力を持つ人々が，能力を持たない人々 に比べて社会経済的環境の変化に柔軟に対応できる ことは，すでに帝国内のいくつかの地域において確 認されている21)。こうした集団の存在によって，地 域構造の変化はより速く進展するものと考えられる (Hoyler and Meusburger 1997).

住民のイノベーション受容のプロセスを規定する 要素としての地域社会の構造にも注目したい．たと えば言語や宗教，文化などが異なる民族集団が存在 する地域では, 所得や生活水準に明確な格差が生じ, それが地域全体におけるイノベーション受容のプロ セスの進度を左右するからである (Meusburger 1998: 30-33).

多民族国家である帝国では，諸民族間にかなりの
社会的格差が存在していた (Good 1986: 139-143). 一方, 帝国内において民族集団の健康状態を比較す ると, 集団間には総じて明瞭な差を認めることがで きる．帝国を構成する主な民族集団ごとに身体の衰 弱による不適格者数の徵兵検查の受検者に占める割 合を集計すると（表 1)，ポーランド系，ウクライ ナ系, ルーマニア系, クロアチア系は, 年次を問わ ず一貫して高い率を示す。これに対して，不適格率 が比較的低い民族集団としてドイツ系，チェコ系， ハンガリー系があげられる。 もちろん，現実はさほ ど単純ではない，当時の民族集団そのものの定義が 必ずしも一様ではなかった上に，同じ民族集団でも 地域によって社会的地位は異なり, 健康状態も多様 であった (Prinzing 1906)。しかし，こうした対 応関係から, 帝国内における各民族の職業, 所得水 準, 識字能力, 学歴など社会経済的特性の違いを知 ることができる.

個々の地域の政治・社会制度の意義も指摘してお きたい. たとえば帝国では, ウィーンやブダペスト などの都市と周辺の農村との間はもちろん, 農村の 特徵も地域的に著しく異なっていた. 帝国内のそう した差異は，すでに 18 世紀にかなり明瞭に認めら れた．帝国西部（とくにチロル地方）では，教会の 


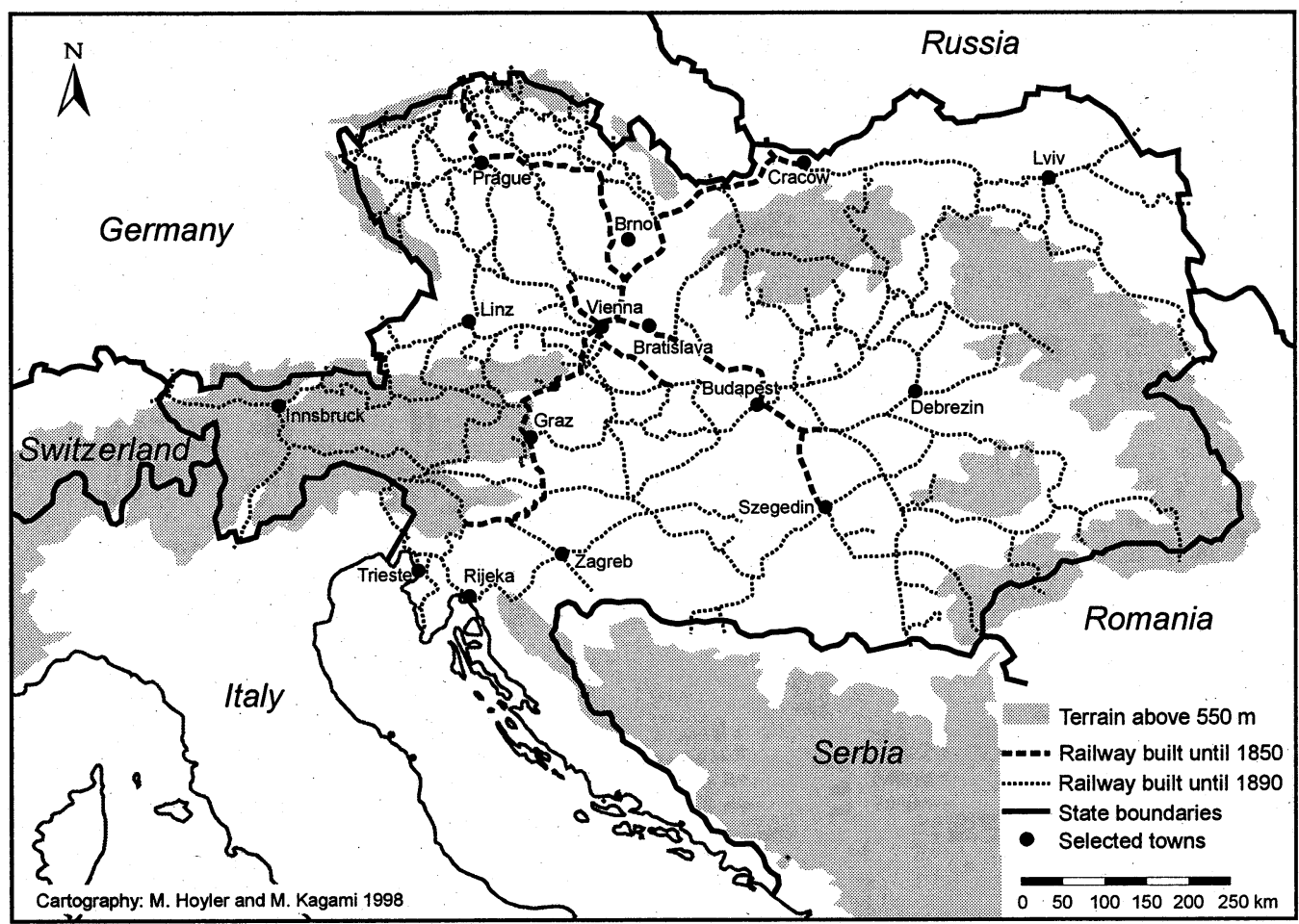

図 8 鉄道網の発達 $(1890$ 年まで $)$

Fig. 8 Development of railroads in the empire until 1890 After Magocsi (1993: 91)

支配から解放された農民が多く (Henning 1969: 46-98), そうした背景から，19 世紀後半には，農 民の多くは経済的に自立しており，彼らは意思決定 の機会をより多く持っていた．所有農地が比較的小 規模ゆえに出稼ぎなどの空間的移動も積極的に行わ れ，地域外との接触が頻繁になされてきた（Fassmann 1991, 1996).

これに対して, 東部のハンガリー王国やガリツィ ア地方では, 貴族や領主による大土地所有と農奴制 が存在し, 農民は行動や経済活動が制限され, 農業 労働を強制された．東部の農村地域における小作人 の貧困と，不十分な生活基盤が，国内 (Spiss 1993: 73-75; Burmeister and Rollinger 1995) はもちろ ん，ドイツやアメリカ合衆国など国外 (Fassmann and Münz 1995; Pichler 1996) への人口流出を
促した ${ }^{22)}$ 。つまり，こうした極端に異なる農村社会 の構造が, 地域でのイノベーションの受容動向を規 定する，いわばフィルターとして作用している.

以上に述へた地域構造は，さらに政策や交通の整 備など地域外からのさまざまなイノベーションによ って規定される.たとえば帝国内における地域変化 は, 鉄道網の整備のプロセス（図 8 ) と符合してい る. 帝国では 19 世紀半ば以降, 首都ウィーンを中 心にしたカイザー・フェルディナント北部鉄道, カ イゼリン・エリーザベト西部鉄道, 南部鉄道, ブダ ペストを中心にしたハンガリー国営鉄道など産業化 推進の旗手としての鉄道路線が帝国内に張り巡らさ れた (Bachinger 1973: 276-303; Jordan 1990). それは, 西から東への工業化のプロセスと連動し, ウィーンやブダペスト，プラ八などの工業・商業中 
心地と, トランシルヴァニア, ガリツィア, ダルマ チアの諸地方に代表される農村地域という中心地域 と周辺地域の対照をきわめて明瞭なものにした ${ }^{23)}$.

その結果, 帝国内にはウィーンやブダペストなど の中心都市，あるいはボへミア地方などの工業中心 地と, そこから遠隔の周辺山地, とくに帝国東部の 農村部との間に著しい地域経済の格差が現れている (Komlos 1983: 214-220). もちろん, 都市におけ る低い健康水準についても触れておかねばならない． 19 世紀後半における帝国の都市（とくにウィーン とブダペスト）では，上下水道の整備や資本の蓄積 による生活水準の向上が見られた一方で, 農村地域 からの低賃金労働者の流入と, 低級住宅地の形成に よって不健康な地区が出現した(Fassmann 1991). 都市・農村間における住民の健康状態の格差が, 必 ずしも経済水準のみではとらえきれないことも事実 である24)。

1850 年代から 1860 年代にかけて, 帝国は好景気 に恵まれ，製鉄業や繊維工業を機軸にした産業化を 一気に進めた。 その後, 1870 年代に不況期を迎え, 帝国東半部のハンガリーにおいては一時的な好景気 があったものの, 帝国全体の経済成長は比較的ゆっ くりとしたものになった: しかし,この間, 経済水 準とそれに関連する生活水準には，一貫して帝国内 に明らかな東西間格差が存在した'(Gross 1985: 224-232). 一方, 徵兵検查結果から引き出された健 康水準にも, 明瞭な東西間格差が認められた。この ことから健康水準の格差が, 19 世紀後半の工業化・ 近代化が進行した時期における帝国内の東西間での 格差, 言い換えれば地域変化の程度の差を歴然と示 したものと判断できる.

\section{V おわりに}

本稿では, オーストリア・ハンガリー帝国におけ る徵兵検査結果に関するデー夕を用いて, 徽兵不適 格理由としての身長, 身体上の障害（身体の衰弱，
甲状腺種, クレチン病, 歯の疾患) の地域差を描写 し ${ }^{25)}$, 住民の健康状態の地域差と地域の特性との対 応についての考察を試みた。

19 世紀後半のヨーロッパでは, 産業革命以来の 都市部を中心とする商工業の急激な発展が生じ，そ の結果, 都市と農村など地域間の格差が著しく拡大 した．帝国内には，そうした地域变化とともに明瞭 な地域間格差が存在した。本稿では, 住民の健康状 態が明瞭な東西格差を示すことに注目し，それが地 域の経済水準や病院の設置・医療担当者の配置など 医療・衛生施設の整備, 生活水準の地域差之関連す ること，さらには鉄道建設に代表されるような地域 外からのイノベーションとそれを受容するか否かを 決定する住民の態度によって規定されるとの解釈を 提示した. つまり，地域が工業化や近代化という变 化を経験し，そのプロセスの遅速が健康状態の地域 差に反映されるという構造を指摘した，今後は，帝 国における健康データを用いたよりミクロな地域ス ケールでの分析を進めることによって，これらの諸 点を実証してゆく必要があるだろう26).

最後に，帝国内における地域間格差に基づいて， ヨーロッパ全域レベルでの空間構造に言及しておき たい. 19 世紀後半のヨーロッパでは, 工業化や近 代化などのイノベーションは北西ヨーロッパから次 第に周辺地域に波及した (Stieglbauer 1992)。こ のことは，帝国領内において，先に述べたようなイ ノベーションのボへミア地方やチロル地方など北西 部から東部への浸透のプロセスと符合する.この点 で，帝国内の地域間格差はヨーロッパ全域における 地域間格差の一部を示している可能性が指摘できる. ヨーロッパ全域の空間構造は, 社会的, 経済的, 文化的側面から, 北西ヨーロッパもしくはヨーロッ パ中央部を核心地域とし，その周囲に周辺地域が存 在するというフレームワークで論じられている27). 近年における東西ヨーロッパの構造の変化を機に, そうした構造の持続性 (Gritsai and Treivish 
1990a,b) が指摘されている. つまり, 現在あるヨ 一ロッパの構造がとりわけ産業革命期に強く形成さ れ, 以来その構造が持続されているという論 (Ilbery 1984; Terlouw 1996) が相次いで出されている. それだけに，帝国内にある地域間格差を検討する意 義は大きい。

本稿は, 加賀美が 1997 年度に Alexander von Humboldt 財団の奨学研究員としてドイツに滞在した際，モ イスブルガーをはじめ, ハイデルベルク大学地理学研究 室のスタッフと相互に繰り返した討論の成果である. か かる機会を与えてくださった財団に心から感謝したい。

なお，本稿を作成するにあたり，八イデルベルク大学 の M. Hoyler, J. Weick 両君には資料整理などでお世 話になった．記してお礼を申し上げる。

(1998年 5 月 8 日) (1999 年 4 月 10 日)

注

1) オーストリア・ハンガリー帝国は, 1867 年のアウス グライヒ以来, 帝都ウィーンを中心とする西半部のオー ストリア（実際には正式の名称を持たなかった）と，ブ ダペストを中心とする東半部のハンガリー王国（皇帝が 国王を兼任）からなる二重帝国であった：それは，帝国 内に外交, 軍事, 国家財政を除くすべての国家制度を別 個に持つ二つの地域が併存するきわめて特殊な形態であ った (Kann 1977: 303-307).なお 19 世紀末の帝国は, ロシアを除くヨーロッパ最大の領土 (約 68 万 $\mathrm{km}^{2}$ ) とドイツに次ぐ人口（約 5 千万）を擁していた.

2) この点は, とりわけ Pyle (1979: 9-11) や Meade et al. (1988: 4-8) : によって強調されている. なお, 住民 の健康状態が地域的に異なることは, すでに世界各地の さまざまな疾病地図において確認されている。棟でも， 疾病死亡率が地域的に異なることが指摘され，その地理 学的分析の意義が強調されている（たとえば, Kagami 1991: 65-68).

3) ドイツの社会地理学は, その体系化の過程で地域の構 造や変化のプロセスを解明するための手掛かりとなるよ うな社会指標を模索してきた． かかる指標はまず，居住 や教育, 余㗇といった人間集団の基本的機能の中に求め られた (Maier et al. 1977: 18). さらに, 地域間の格 差の持続性を論じるために, 生活条件を反映した社会指 標として死亡現象に着目した研究が相次いで提出されて いる. たとえば乳児死亡率と工業労㗢者の所得という二
つの社会的指標を用いて南ドイツの生活条件の地域差を 論じた Thieme $(1984,1985)$; 死亡率を用いてプロイ センの都市の類型化を試みた Laux (1985), 死因別死 亡率を用いて日本の生活条件の地域差を分析した Lützeler (1994) などによって, 社会的指標としての死亡 現象が論じられている. しかし, 入手可能なデー夕の制 約, 複雑に関与する要因などの理由から, 疾病・死亡現 象の社会指標としての汎用性になお疑問が残る (Maier and Meusel 1995: 172-173) ことも付言せねばならな い.

4). 都市における急激な工業化が都市住民の食事内容や栄 養水準, 健康状態を著しく変化させた点は, すでにドィ ッの諸都市を事例にして論じられている（たとえば, Abel 1981; 見市 1987).

5) たとえば, Carter et al. (1996) を参照されたい.

6）住民の健康状態に関する統計は, 他の統計に比へて必 ずしも十分に整備されてはいない，健康そのものの概念 がきわめて漠然としており, 数值化が困難なことが理由 と考えられる. この問題を克服するために, 従来の地理 学研究において, 統計を用いずに医療施設ごとの患者に 関する健康保険の診療報酬明細書（レセプト）に着目し て，住民の健康状態をとらえた研究例がある（たとえば， Meusel 1987; 谷島 1988).これは, とくにミクロな地 域スケールでの研究に有効である.

7) たとえば, Prinzing (1903) の研究がある.

8 ）帝国に限らず, 19 世紀後半以降のヨーロッパ諸国に おける徵兵検査結果デー夕には, 健康状態 (疾病, 障 害) のみならず, 身長や胸囲, さらに識字能力（のちに (学歴), 職業, 宗教, 母語, 場合によっては父親の職 業も記載されている. この点で, 徵兵検查データが当時 の地域住民の健康状態を分析するための有用な資料であ ることはいうまでもない，医学地理研究において, 健康 デー夕の入手の可能性が限られ，ゆえにそれに代わる歴 史的資料の有用性が指摘されているが. (Jones and Moon 1992)，一方では，かかる資料がこれまで地理学 においてほとんど利用されてこなかったこと自体に，注 意の目を向けるべきであろう (Meusburger 1995: 204).

9 ）帝国の徴兵検查は, 1868 年 12 月 5 日公布の徵兵法に 基づいて実施された。徵兵検査該当者名簿の作成は, 各 市町村ごとに教会簿（出生・洗礼簿）を基礎にして個別 に生存と在住を確認することから始められた. 市町村ご とにまとめられた名簿は，補管区ごとに集計され，国勢 調查や志願兵名簿に照会した上で最終的に作り上げられ た. 不適格者には次年, 次々年に再度検查が行われた。 三回目の検查で不適格になった者は，徵兵検查名簿から 抹消された。

10）分析の資料として，ウィーンの国立オーストリア統計 局に所蔵されている『軍統計年鑑』(Militärstatistische 
Jahrbuch 1870-1914）全 45 巻を利用した.

11）広大な帝国における住民の健康状態を示す唯一の資料 である. 同時期の統計としてドイツ語で記載された『帝 国統計年鑑』にも死因別, 州別の統計があるが，これは オーストリア側に限られる. オーストリアとハンガリー からなる帝国では, 両地域に別の行政組織が置かれ, 双 方で別個に統計年鑑が刊行されたためである. 軍事部門 は外交, 財務とともに両地域に共通の組織として残され たため，帝国全域にわたる資料が編集された，なお，こ のほかに徴兵検查結果の個票を利用することもできるが, 必ずしも保存されているとは限らない，筆者らはすでに， チロル軍管区における 1910 年の徵兵検査受検者の結果 個票を用いて疾病の空間構造を論じたが (Kagami 1992; Meusburger 1995)，この資料はチロル州公文書 館で発見，入手したものである.

12) 手続の詳細については Meusburger (1995) を参照 されたい.

13)『軍統計年鑑』には，軍管区およびその下部単位であ る補管区ごとに，不適格理由別に千人あたりの徵兵不適 格者数が掲載されている. 不適格理由の分類は必ずしも 一貫していない. 1885 年には, 全国を構成する 15 の軍 管区および 107 の補管区ごとに, 18 の大分類と 20 の 細分類からなる不適格理由別の割合が掲載されている. 具体的には，身体の衰弱，一般的な疾患および血液の疾 患 (瘰㿇, 結核), 悪性新生物, 神経の疾患（てんかん, 聴覚・言語障害, クレチン病), 眼の疾患（トラコーマ, 角膜の混濁之瘏痕, 近視, 斜視), 耳の疾患, 呼吸器の 疾患, 循環器の疾患 (静脈瘤, 甲状腺腫), 消化器およ び付属器の疾患（歯の疾患, 下腹部ヘルニア, 直腸ヘル ニア), 性病・梅毒を除く泌尿器および性器の疾患, 梅 毒, 梅毒を除く皮膚の慢性疾患（脂足, 広範囲にわたる 瘾痕), 骨の疾患, 関節の疾患 ( $\mathrm{X}$ 脚, 外反膝, 偏平 足), 筋肉・腱・滑液囊の疾患, 傷害; 兵役忌避のため の自己虐待, 奇形 (胸部・骨盤・脊柱の奇形) である. なお,これらが現在の疾病分類と異なっておりここで は当時の疾病の定義を記した Höfler (1899) に基づい て筆者が名称を特定したこと，また『軍統計年鑑』では, 不適格理由として最も重度の疾病ないし障害一つのみが 記録の対象とされたために，この統計が必ずしも受検者 の健康状態すべてを把握したものでないことを付記して おきたい.

14） 1900 年前後における徽兵検査の適格者率が, ドイツ 帝国で約 55\%，フランスで約 45\% であることと比較す れば,オーストリア・ハンガリー帝国における適格者率 がいかに低いかは明らかである.

15）ただし, 以下の点に注意を要する. 徵兵検査では, 複 数の疾病・障害を持つ受検者については片足の欠損や失 明など重度の障害が優先的に記録されたため，それらに
ついての記録がかなり正確である反面, 軽度の障害には 十分に注意が払われていない. したがって, 個々の疾 病・障害についての件数の推移を見ると, 年によってか なりばらつきがある. また徴兵検査データには, 死に至 らないような疾病・障害が把握できるという利点がある 一方で, 若年者を対象にした検查ゆえに痛風のような高 齢者に多い疾患がほとんど現れてこないという難点があ る.

16) たとえば Pounds (1985: 175-178) は, 全ヨーロッ パスケールにおいて帝国内の東西格差に言及するにとよ゙ まっている.

17）身長は, 栄養状態をはじめとする住民の生活水準全般 を端的に示し，それゆえに地域経済の活性化，とくに19 世紀ヨーロッパにおいては工業化の程度を測る有効な指 標として評価できる (Komlos 1989: 43-50).

18） 19 世紀後半のチロル地方南部における地域変化を論 じた Penz (1984: 89-90) は, トウモロコシ主体の食習 慣に起因する栄養欠乏症ペラグラの発生数が, 地域経済 の変化とともに減少すること, しかし, 食習慣と疾病発 生件数の変化が地域経済の変化に比べてゆっくりしたも のであることを指摘している. なお，一般に地域住民の 食習慣は, 都市化などによる地域構造の急激な変化に際 してもそれほど急には変化しない傾向にあることが確認 されている（足立ほか 1997）.

19）たとえばアルプス山間地の隔絶山村では, 19 世紀後 半において三ないし四親等間の婚姻も珍しくなかった (Fliri 1996: 161-163).

20) Phillips (1994) は, タイの都市と農村の死因を今世 紀初めから経年比較して, 死因の種類が生活水準の格差 や改善のプロセスと対応することを示している.

21）識字能力を持つ人々は, 一般に社会経済的変化に柔軟 に対応することができる，たとえば帝国最西端に位置す るフォアアールベルク地方では住民の識字率が高い水準 にあり,このことが, 隣接するスイス東部からの新しい 技術や情報をいち早く受け入れ, 19 世紀後半における 繊維工業の発展 (綿織物, 刺繡) を促し, 帝国きっての 産業先進地域へと発展する素地となった (Meusburger 1991).

22）農村部での伝染病の減少による人口増加が，人口過剩 と人口流出を促した（Livi-Bacci 1986）ことも指摘し ておきたい.

23）交通の整備と連動して, ウィーンやブダペストなど都 市・工業中心地への帝国各地からの人口の集中（Fassmann and Münz 1996) が急激に進行した.

24）都市内部には極端な社会的格差が現れ，その結果，都 市における死亡率は, しばしば農村のそれよりもむしろ 高くさえなった(Laux 1985).

25）ここに取り上げなかった疾病・障害の多くは複雑な地 
域的パターンを示し, 特定の集中地域を確認することが できなかった．しかしこのことは，これらの疾病や障害 が「空間的に関連した事象」であることを否定するもの ではなく、むしろ単位地域の規模など本稿で対象にした 地域構成が，意味のある推論を得るのに不適当であった とみなすべきであろう.

26）オーストリア・ハンガリー帝国が残した膨大な統計資 料は, 数多くの単位地域ごとに集計されており, 空間分 析にとってきわめて有用である．豊富な統計デー夕を用 いた帝国内の地域間格差の分析が，現代の中央ヨーロッ パの地域構造を解明する糸口を提供するはずである.

27) ヨーロッパの地域構造については, 同心円構造論 (Stieglbauer 1992; Jordan 1996: 418) や, Brunet が 提唱した青いバナナの構造を基本にした議論 (Dunford and Perrons 1994; Ehlers 1997) が知られるが，いず れもヨーロッパの核心地域と周辺地域の対照性をとらえ ようとしたものである.

\section{文 献}

足立已幸・加賀美雅弘・山本妙子 1997. 食塩選択行動之 環境要因の構造に関する食生態学的研究, 世帯及び地域 の食堤選択に関する地理学的, 食生態学的研究. ソルト サイエンス研究財団編『平成 7 年度助成研究報告集 II

生理・食品・栄養系編』5-20.ソルトサイエンス研究財 団.

加賀美雅弘・籾山政子 1982 . 医学地理学の最近の動向. 人文地理 $34: 323-343$.

北原龍二 1977。保健・医療問題と軍隊一日本社会医療 史における軍隊の意義. 東京教育大学文学部社会学教室 編『現代社会の実証的研究, 東京教育大学社会学教室最 終論文集』55-65. 東京教育大学文学部社会学教室.

見市雅俊 1987. 栄養・伝染病・近代化. 社会経済史学 53: 90-124.

南 直人 1998. 『ヨーロッパの舌はどう変わったか一十 九世紀食卓革命』講談社.

谷島久雄 1988. 積雪山村住民の医療施設利用行動—— 新 潟県上川村の事例. 駿台史学 72: 175-197.

Abel, W. 1981. Stufen der Ernährung: Eine historische Skizze. Göttingen: Vandenhoeck und Ruprecht. アーベル, W. 著, 高橋秀行・中村美幸・桜井健 吾共訳 1989. 『食生活の社会経済史』 晃洋書房.

Bachinger, K. 1973. Das Verkehrswesen. In Die Habsburger Monarchie 1848-1918, Band I: Die wirtschaftliche Entwicklung, ed. A. Brusatti, 278-322. Wien: Verlag der Österreichischen Akademie der Wissenschaften.

Burmeister, K. H. and Rollinger, R. 1995. For- schungsgeschichte und Intention des vorliegenden Bandes: 100 Jahre wissenschaftliche Beschäftigung mit der italienischen Einwanderung: Ein kurzer Abriß. In Auswanderung aus dem Trentino - Einwanderung nach Vorarlberg: Die Geschichte einer Migrationsbewegung mit besonderer Berücksichtigung der Zeit von 1870/80 bis 1919, ed. K. Burmeister and R. Rollinger, 11-26. Sigmaringen: Jan Thorbecke Verlag.

Carter, F., Jordan, P. and Rey, V. eds. 1996. Central Europe after the fall of the Iron Curtain: Geopolitical perspective, spatial patterns and trends. Frankfurt A. M.: Peter Lang.

Dunford, M. and Perrons, D. 1994. Regional inequality, regimes of accumulation and economic development in contemporary Europe. Transactions, Institute of British Geographers, NS 19: 163-182.

Ehlers, E. 1997. Zentren und Peripherien: Strukturen einer Geographie der europäischen Integration. In Deutschland und Europa: Historische, politische und geographische Aspekte, ed. E. Ehlers, 149-171. Bonn: Ferdinand Dümmlers Verlag.

Fassmann, H. 1991. Einwanderung, Auswanderung und Binnenwanderung in Österreich-Ungarn. Österreichische Osthefte 31(1): 51-66.

Fassmann, H. 1996. Auswanderung aus der österreichisch-ungarischen Monarchie 1869-1910. In Auswanderungen aus Österreich: Von der Mitte des 19. Jahrhunderts bis zur Gegenwart, ed. T. Horvath and G. Neyer, 33-55. Wien: Böhlau Verlag.

Fassmann, H. and Münz, R. 1995. Einwanderungsland Österreich? Historische Migrationsmuster, aktuelle Trends und politische Maßnahmen. Wien: $\mathrm{J}$ \& V-Edition Wien-Dachs-Verlag.

Fassmann, H. and Münz, R. 1996. Between melting pot and ethnic fragmentation: Historical and recent immigration to Vienna. In EthniCity, ed. C. C. Roseman, H. D. Laux and G. Thieme, 165-185. Boston: Rowman \& Littlefield Publishers.

Fliri, F. 1996. Hans Kinzl und die Innsbrucker Schule der Bevölkerungsgeographie. Mitteilungen der Österreichischen Gesellschaft 138: 147-181.

Floud, R., Wachter, K. and Gregory, A. 1990. Height, health and history. Cambridge: Cambridge University Press.

Friedl, H. 1979. Die Gesundheitsverhältnisse in Österreich im 19. Jahrhundert. In Geschichte und 
Ergebnisse der zentralen ämtlichen Statistik in Österreich 1829-1979, ed. Österreichisches Statistische Amt, 471-478. Wien: Österreichisches Statistische Amt.

Good, D. 1986. Der wirtschaftliche Aufstieg des Habsburgerreiches 1750-1914. Wien: Böhlau Verlag.

Gritsai, O. and Treivish, A. 1990a. Stadial concept of regional development: The dynamics of core and periphery — A theoretical discussion. Geographische Zeitschrift 78: 65-77.

Gritsai, O. and Treivish, A. 1990b. Stadial concept of regional development: Centre and periphery in Europe. Geographische Zeitschrift 78: 137-149.

Gross, N. 1985. Die industrielle Revolution im Habsburgerreich 1750-1914. In Europäische Wirtschaftsgeschichte. Band 4., ed. C. Cipollá and K. Borchardt, 203-235. Stuttgart: Gustav Fischer Verlag.

Henning, F.-W. 1969. Dienste und Abgaben der Bauern im 18. Jahrhundert. Stuttgart: Gustav Fischer Verlag.

Höfler, M. 1899. Deutsches Krankheitsnamen-Buch. München: Verlag von Piloty \& Loehle.

Hoyler, M. and Meusburger, P. 1997. Regionale Unterschiede bei der Verwirklichung der allgemeinen Schulpflicht und der Alphabetisierung der Bevölkerung in der österreichischen Monarchie in der zweiten Hälfte des 19. Jahrhunderts. Heidelberg: Geographisches Institut der Universität Heidelberg (Arbeitsbericht über das DFG-Projekt ME 807/10-1).

Ilbery, B. 1984. Core-periphery contrasts in European social well-being. Geography 69: 289-302.

Jones, K. and Moon, G. 1987. Health, disease and society: A critical medical geography. London: Routledge and Kegan Paul.

Jones, K. and Moon, G. 1992. Medical geography: Global perspectives. Progress in Human Geography 16: 563-572.

Jordan, P. 1990. Die Entwicklung der Fremdenverkehrsströme in Mitteleuropa (1910-1990) als Ausdruck politischer und wirtschaftlicher Veränderungen. Mitteilungen der Österreichischen Geographischen Gesellschaft 132: 144-171.

Jordan, T. 1996. The European culture area: A systematic geography. 3rd edition. New York: Harper Collins College Publishers.

Kagami, M. 1991. A geographical study on regional variations of disease mortality. Science Report of the Institute of Geoscience, University of Tsukuba (Sec. A) 12: 65-89.

Kagami, M. 1992. Regional variations of diseases in South Tyrol and Trentino, northern Italy: A study of historico-medical geography. Geographical Review of Japan 65 B : 1-14.

Kann, R. A. 1977. Geschichte des Habsburgerreiches, 1526 bis 1918. Wien: Böhlau.

Komlos, J. 1983. The Habsburg monarchy as a customs union: Economic development in AustriaHungary in the nineteenth century. Princeton: Princeton University Press.

Komlos, J. 1989. Nutrition and economic development in "the eighteenth-century Habsburg monarchy. Princeton: Princeton University Press.

Laux, H.-D. 1985. Mortalitätsunterschiede in preussischen Städten 1905: Ansätze zu einer Erklärung. Colloquim Geographicum 18: 50-82.

Learmonth, A. 1988. Disease ecology: An introduction. Oxford: Basil Blackwell.

Livi-Bacci, M. 1986. Fertility, nutrition, and pellagra: Italy during the vital revolution. Journal of Interdisciplinary History 16: 431-454.

Lützeler, R. 1994. Räumliche Unterschiede der Sterblichkeit in Japan: Sterblichkeit als Indikator regionaler Lebensbedingungen. Bonn: Ferdinand Dümmlers Verlag.

Magocsi, P. 1993. Historical atlas of East Central Europe. Seattle: University of Washington Press.

Maier, J. and Meusel, M. 1995. Der Faktor Raum in der Geomedizin: Beispiele neuer Untersuchungen in Oberfranken. In Krankheit und Raum, ed. W. Fricke and J. Schweikart, 165-174. Stuttgart: Franz Steiner Verlag.

Maier, J., Paesler, R., Ruppert, K. and Schaffer, F. 1977. Sozialgeographie. Braunschweig: Westermann. マイヤー, J.・ペスラー, R.・ルッペルト, K.・シャッファー, F. 著, 石井素介・水岡不二雄・朝 野洋一訳 1982.『社会地理学』古今書院.

Maier, J. and Troeger-Weiß, G. 1987. Geomedizin: Gesundheitsökonomie und Gesundheitspolitik. Universität Bayreuth, Arbeitsmaterialien zur Raumordnung und Raumplanung 31: 214-258.

Meade, M., Florian, J. and Gesler, W. 1988. Medical geography. New York: Guilford Press.

Meusburger, P. 1991. Die frühe Alphabetisierung der Bevölkerung als Einflußfaktor für die Indu- 
strialisierung Vorarlberg? Jahrbuch des Vorarlberger Landesmuseumsvereins 135: 95-100.

Meusburger, P. 1995. "Stellungslisten" und "Militärstatistische Jahrbücher" der österreichisch-ungarischen Monarchie als Quellen für die geomedizinische Forschung. In Krankheit und Raum, ed. W. Fricke and J. Schweikart, 203-236. Stuttgart: Franz Steiner Verlag.

Meusburger, P. 1998. Geographie des Bildungs- und Qualifikationswesens. Heidelberg: Akademischer Verlag Spektrum.

Meusburger, P. and Klinger, A. eds. 1995. Vom Plan zum Markt: Eine Untersuchung am Beispiel Ungarns. Heidelberg: Physica-Verlag.

Meusel, M. 1987. Psychische Störungen als Gegenstand von Epidemiologie und Geographie. Universität Bayreuth, Arbeitsmaterialien zur Raumordnung und Raumplanung 31: 1-213.

Murken, A. 1992. Geschichte der Medizin von Erwin A. Ackerknecht, 7. Auflage. Stuttgart: Ferdinand Enke Verlag.

Penz, H. 1984. Das Trentino: Entwicklung und räumliche Differenzierung der Bevölkerung und Wirtschaft Welschtirols. Innsbruck: Universitätsverlag Wagner.

Phillips, D. 1994. Epidemiological transition: Implications for health and health care provision. Geografiska Annaler 76 B : 71-89.

Pichler, M. 1996. Die Vorarlberger Amerikawanderung bis'1938. In Auswanderungen aus Österreich: Von der Mitte des 19. Jahrhunderts bis zur Gegenwart, ed. T. Horvath and G. Neyer, 57-80. Wien: Böhlau Verlag.

Pounds, N. 1985. An historical geography of Europe 1800-1914. Cambridge: Cambridge University Press.

Prinzing, F. 1903. Die Todesursachen in den europäischen Staaten 1891-1900. Statistische Monatsschrift 29: 767-807.

Prinzing, F. 1906. Handbuch der medizinischen Statistik. Jena: Verlag von Gustav Fischer.

Pyle, G. 1979. Applied medical geography. New York: John Willy and Sons.
Schaffer, F. 1997. Interaktive Sozialgeographie: Zur Konzeption einer praxisbegleitenden Implementations-Forschung. In Socialnogeografski problemi, ed. M. Klemenčič, 31-58. Ljubljana: Narodna univerzitetna knjižnica.

Seidler, E. 1993. Geschichte der Medizin und der Krankenpflege, 6. Auflage. Stuttgart: Verlag W. Kohlhammer.

Spiss, R. 1993. Saisonwanderer, Schwabenkinder und Landfahler: Die gute alte Zeit im Stanzertal. Innsbruck: Universitätsverlag Wagner.

Spree, R. 1981. Soziale Ungleichheit vor Krankheit und Tod: Zur Sozialgeschichte des Gesundheitsbereichs im Deutschen Kaiserreich. Göttingen: Vandenhoeck und Ruprecht.

Stieglbauer, K. 1992. Die Kulturregion Europas. Mitteilungen der Österreichischen Geographischen Gesellschaft 134: 93-114.

Terlouw, K. 1996. A general perspective on the regional development of Europe from 1300 to 1850 . Journal of Historical Geography 22: 129-146.

Thieme, G. 1984. Disparitäten der Lebensbedingungen: Persistenz oder raum-zeitlicher Wandel? Untersuchungen am Beispiel Süddeutschlands 1895 und 1980. Erdkunde 38: 258-267.

Thieme, G. 1985. Sozialindikatoren in der Geographie: Möglichkeiten und Probleme der Analyse regionaler Disparitäten. Colloquium Geographicum 18: 213-241.

Tilly, R. 1992. Rezension: John Komlos, Nutrition and economic development in the eighteenth-century Habsburg Monarchy: An anthropometric history, Princeton 1989. Geschichte und Gesellschaft 18: 265-270.

Wörterbuch-Redaktion des Verlages 1998. Pschyrembel Klinisches Wörterbuch, 258. Auflage. Berlin: Walter de Gruyter.

Zaniewski, K. 1992. Regional inequalities in social wellbeing in Central and Eastern Europe. Tijdschrift voor Economische en Sociale Geografie 83: 342-352. 


\title{
Regional Disparities in the Austro-Hungarian Empire with Special Reference to the Health Conditions of Military Conscripts
}

\author{
Masahiro KAGAMI*, and Peter MEUSBURGER** \\ (Department of Geography, Tokyo Gakugei University*, \\ Institute of Geography, University of Heidelberg**)
}

In this study the authors attempt to elucidate regional disparities within the territory of the former Austro-Hungarian Empire in the latter half of the 19th century, particularly in reference to the health conditions of the population. Variables such as mortality rates have previously been analyzed in geographical studies and their significance as social indicators discussed. However, the number of such papers is limited, because often relevant additional data on health are not available for spatial analysis.

This study analyzes health data from military conscription records published in Military Statistical Yearbooks (Militärstatistische Jahrbücher) of the empire. Some advantages of such data for analysis can be pointed out: 1) they reflect the general health conditions of the population, listing diseases and disorders as reasons for excluding recruits from military service in each military district (Militärbezirk); and 2) the quality of the data is comparatively homogeneous for the vast territory of the empire and allows the analysis of regional disparities in a large area of Central Europe which today consists of several countries. During the 19th century, drastic changes occurred in Europe's regional structure, which makes the analysis of their impact on health conditions a relevant topic.

To determine regional disparities, specific diseases and disorders of military recruits were selected: weakness of the body and short physical stature (less than $155 \mathrm{~cm}$ ) were chosen to reflect general health conditions; and goiter, cretinism, and dental disorders to reflect specific diseases.

These diseases and disorders show regional differences. There is an east-west gradient as well as a town-country gradient in the empire. The regional structure can be explained as a system which consists of relations between socioeconomic and political elements that affect health conditions. In this regard, health conditions should be one of the aspects utilized to grasp regional structures.

This article concludes with a reference to regional disparities in Europe. The east-west gradient in the Austro-Hungarian Empire can be viewed as an aspect of the central-periphery pattern in Europe. In these terms, the empire can serve as a keyhole through which the regional disparities within Europe can be perceived.

Key words: regional disparity, social indicator, health conditions, military conscription, the AustroHungarian Empire 